\title{
KUMMWANGALELA GUEBUZA \\ THE MOZAMBICAN GENERAL ELECTIONS OF 2004 IN MUIDUMBE AND THE ROOTS OF THE LOYALTY OF MAKONDE PEOPLE TO FRELIMO*
}

For strategic reasons, Makonde people were the backbone of the Frelimo army during the Mozambican war of independence. Since then, Makonde people are almost fanatically devoted to Frelimo. During the Mozambican general elections of December 2004, the people of the district of Muidumbe enthusiastically supported the candidature of Armando Emílio Guebuza throughout a massive electoral campaign, during which members of the other parties were often threatened and harassed. The elder women of Muidumbe organised a special ceremony to propitiate Guebuza's candidature, as if he were a boy undergoing initiation (likumbi). This shows how politics and ritual are deeply intertwined in Makonde society.

This paper addresses the issue of Makonde "ethnic" loyalty to Frelimo, through a description of the 2004 elections in Muidumbe, and historical analysis. It will try to show how Frelimo became a cornerstone of Makonde identity because of the processes of radical transformation that the Makonde society underwent during the war of liberation and in its aftermath.

\section{Kummwangalela Guebuza \\ Les élections mozambicaines de 2004 à Muidumbe et les racines de la loyauté du peuple maconde envers le Frelimo}

Pour des raisons stratégiques, les Macondes ont participé massivement à la lutte de libération nationale au Mozambique. Depuis, les Macondes sont des partisans farouches du Frelimo. À l'occasion des élections générales tenues en décembre 2004, les gens du district de Muidumbe ont soutenu avec enthousiasme la

* Research for this article was carried in the District of Muidumbe between November 2004 and January 2005, in the context of a Ph.D. on Makonde masquerades that I am doing at EHESS, Paris, under the direction of Jean-Loup Amselle («Mapiko : création et révolution. Danses masquées du people Makonde du Nord du Mozambique »). During these months, I shared the thrill and the burden of fieldwork with Sandra Lourenço, a photographer working on Makonde female initiation rituals. We experienced the intermingling of politics and ritual in our work as well as in our daily routine. At the time, my house had been rented to the District Commission for Electoral Transparency, and the very room where we slept served as a bureau from 7 to 15. Sandra has documented photographically the political engagement of Makonde women during the electoral campaign. This work owes enormously to the support, care, enthusiasm, insightfulness and friendship that she provided on the field. I also thank heartily Pedro Justino Seguro, administrator of Muidumbe and his wife Josina, who came to be my Makonde family in Muidumbe; and all the staff of the electoral campaign in Muidumbe that have allowed me to follow through the campaign, often in the back of their truck; in particular Nshonyo and Paulo Ntumbati. As usual, I thank my friends and field assistants Mario "Mali Ya Mungu" Matias; Evaristo "Angelina" Januario and Fidel Suka Mbalale.

I thank Edward A. Alpers, Michel Cahen and Harry G. West for their precious comments on the first version of this paper. 
candidature d'Armando Emílio Guebuza. Au cours de la campagne électorale, les sympathisants des autres partis politiques ont été menacés et agressés. Certaines femmes âgées de Muidumbe ont organisé une cérémonie spéciale en faveur de l'élection de Guebuza, en agissant comme s'il était un garçon soumis aux rituels d'initiation (likûmbi). Cet épisode témoigne de l'entrelacs entre les domaines du politique et du rituel dans la société maconde.

Cette étude pose la question de la fidélité « ethnique» des Macondes au Frelimo, dans la description des élections de 2004 à Muidumbe nourrie d'analyses historiques. Il retrace les facteurs qui ont fait du Frelimo un pilier de l'identité maconde, et notamment les processus de transformation radicale qui s'enchainèrent dans la société maconde pendant et à la suite de la guerre de libération.

\section{Kummwangalela Guebuza \\ As eleições moçambicanas de 2004 em Muidumbe e as raizes da leadalde do povo maconde para com a Frelimo}

Por razões estratégicas, os macondes participaram maciçamente na luta de libertação cacional em Moçambique. Desde então os macondes são ferozes partidários da Frelimo. Na altura das eleições gerais realizadas em Dezembro de 2004, o povo do distrito de Muidumbe apoiou com entusiasmo a candidatura de Armando Emílio Guebuza. Durante a campanha eleitoral, os simpatizantes dos outros partidos foram ameaçados e agredidos. Algumas mulheres idosas do distrito organizaram uma cerimónia especial a favor da vitória de Guebuza, agindo como se ele fosse um rapaz submetido a rituais de iniciação (likumbi). Este exemplo mostra o entrelaçado entre as áreas do político e do ritual na sociedade maconde.

Este estudo levanta a questão da fidelidade «étnica » dos macondes à Frelimo, através da descrição das eleições de 2004 em Muidumbe, alimentada por análises históricas. Retraça os factores que fizeram da Frelimo um pilar da identidade maconde, e nomeadamente os processos de transformação radical que se encadearam na sociedade maconde durante a guerra de libertação e na sequência da mesma.

Vicente Ululu

Ululu, my friend

Came with a nice helicopter: nguru-nguru

He landed in the city of Muidumbe

The people ran away

To call Chissano

When he arrived to the field

The people stoned him

He's not Chissano!

He is on some mission with Renamo

Shimakonde song ${ }^{1}$

\footnotetext{
${ }^{1}$ In Shimakonde: "Vicente Ululu / Ululu nyagwe / Kwaloka mulikapito shana ngru-ngru. / Andida nawikila njini pamwidumbi / Venenentente kuntukutila /Vanshema Chissano baba / Muwakati wawikile pashuwanja / Venentente vandinjalanga majanga /Anava Chissano jó /Au mwanda umwe Renamo". I recorded this song in Muidumbe, the $26^{\text {th }}$ of July 2004, with the group Ntoji na Lijele of Namande.
} 
A fonso Dhlakama, President of the Renamo (Resistência Nacional de Moçambique) party and leader of the opposition in Mozambique, visited the Muidumbe district only once, the $13^{\text {th }}$ of October 1994 (Cahen 2002: 118-119), as he was campaigning for the first general elections to be held in the country, after almost 15 years of civil war. Muidumbe is a rural district of northern Mozambique that spans over the south-eastern portion of the Makonde plateau and the neighbouring lowlands. It was the cradle of the independence struggle (Luta Armada de Libertação Nacional) led by Frelimo (Frente de Libertação de Moçambique) against the Portuguese (1964-1974), and it is the heartland of the Makonde people, who have been staunch supporters of Frelimo ever since.

In the course of many months of anthropological fieldwork conducted in and around Muidumbe ${ }^{2}$, I heard the story of the visit of Dhlakama a dozen times. True or not, it has become a local legend, and as such it is worth telling.

Dhlakama - so the story goes - arrived on a helicopter, accompanied by his crew, with the objective of holding a political meeting. With him was Vicente Ululu, then number two of Renamo, native of the seat of Muidumbe district, Mwambula. Muidumbeans did not allow Dhlakama to finish the meeting. In October mangoes just begin to give fruits. As the outraged villagers gathered, they found that the stone-hard unripe fruits were most suitable projectiles to hurl at the undesired visitor. Policemen arrested the most riotous, just to release them around the corner with words of encouragement. As Mr. Dhlakama was trying to speak, his wife needed to relieve herself. She asked a woman living in a house around the field for permission to use her latrine. Out of hospitality, the woman allowed her in. When Dhlakama's wife was finished, she found out that her husband and his crew were just about to leave, the helicopter pelted by a hard rain of mangoes.

As exaggerated as this story can $b^{3}$, it is nevertheless true that the woman who opened up her house to Dhlakama's wife (or whoever the woman who asked for permission might be) was thereafter harassed and threatened. An Italian nun living in the local mission of Nangololo publicly defended the woman's behaviour as charitable and Christian. The local government had to intervene in order to appease a group of female Frelimo supporters that wanted to teach a lesson both to the overgenerous woman and to the moralistic nun. Ever since, both women have been labelled as Renamo supporters in Muidumbe.

Frelimo has won all the elections in Muidumbe since 1994, with results embarrassing for the opposition, and almost hardly compatible with what is usually understood as democracy. At the same time, the district has been the stage of acts of political violence against representatives of the Renamo party.

Some political analysts have stressed the unbalance in the country's development under Frelimo's rule 4 . The economy of the southern region of the country boosted, because of the eccentric position of Mozambique's capital city and of the

\footnotetext{
${ }^{2}$ Eight months in 2002, four months in 2003, seven months in 2004.

${ }^{3}$ Cahen gives a totally different version, in which the helicopter leaves after the end of the meeting. However, he relates incidents between Muidumbeans and Dhlakama's crew. He also relates that the helicopter left "after being hit by a big stone" (CAHEN 2002: 199).

${ }^{4}$ M. Cahen insists particularly on this (CAHEN 2000: introduction to the chapter on Mozambique).
} 
proximity with South Africa, whereas the northern provinces were all but forgotten. Muidumbe is located in the northern half of the northernmost province of the country, more than $2500 \mathrm{~km}$ away from Maputo. It is a third-category district, with almost no infrastructure, and its inhabitants struggle daily with poverty and sometimes hunger. Many Makonde are war veterans, and Makonde people ever since the war have held important positions in the army. However, given the state of tremendous underdevelopment of the district, one cannot imagine that the loyalty of Muidumbeans is based on a relationship of patronage with the Frelimo elites based in Maputo.

What is it then, that makes Muidumbeans such staunch followers of Frelimo? Could this phenomenon be understood in terms of "ethnic loyalty"? In this paper I will address the issue of the political loyalty of the Makonde people to the Frelimo party with a multifaceted approach, taking into account history and the postcolonial configurations of identity, belonging and construction of the social self.

\section{Muidumbe 2004, Election Time}

Ten years after the infamous visit of Dhlakama to Muidumbe, elections approached once again ${ }^{5}$. In the elections of 1999 Muidumbe had ranked as the single district in the country most loyal to Frelimo, boasting an impressive $94.1 \%$ of preferences expressed for Frelimo and a $97.8 \%$ for Chissano.

\section{Chissano, Have a Rest!}

Having completed two mandates as a president, Chissano decided to make room to another candidate. During the $8^{\text {th }}$ Congress of the Frelimo party, held in 2002, Armando Emilio Guebuza was appointed Executive Secretary of the Party and candidate to the presidency. Frelimo promoted the image of the new candidate with a government-sponsored national festival of popular dance ${ }^{6}$ and through the distribution of pictures, calendars, and capulanas (kanga) bearing his image. Starting in June 2002, in a few months Muidumbeans were thoroughly familiar with the idea that Guebuza would now be the candidate to presidency and the new leader of Mozambique. They accepted it with no apparent trauma or discontent.

Chissano organised a triumphal journey all over Mozambique as a form of farewell to the nation ${ }^{7}$. He didn't go to Muidumbe, but he hit the nearby town of Mueda on the $16^{\text {th }}$ of July 2004. There he held a meeting with the main objective of announcing his retirement and affirming his complete support for Guebuza's

\footnotetext{
${ }^{5}$ All accounts that follow are based on field notes taken over the electoral process. I had a very close look at the functioning of the electoral machine, as I was having intense contacts with the administration of the district and the campaigning team, that allowed me and Sandra to follow the electoral process when we were not busy with other research activities.

${ }^{6}$ The Eight Congress was given most importance through a National Festival of Popular Dance, that served also as a political tool to present to the rural population the results of the Congress and the new candidate to the Presidency.

${ }^{7}$ Somehow reminding of the triumphal journey of Samora Machel from Rovuma to Maputo, right after the independence.
} 
candidature. A song that was sung during this occasion is expressive of the mood of the participants to the meeting.

Chissano ulota kupumula

Litala lyakupumula undapata

Guebuza kwela!

Langalela kenga mujo Chissano
Chissano, you told us that you are tired to rule You will have time to rest then

Gebuza rise!

Take the lead like your colleague Chissano $\operatorname{did}^{8}$

\section{"Dabusha!"}

Less than a month later, Guebuza travelled to the north of the country to assess the functioning of the structures of the Frelimo party. He planned a stop in Muidumbe the night of the $11^{\text {th }}$ of August.

At that time, the electoral campaign had not started, and Guebuza was visiting the district as the leader of the Frelimo party. The visit, however, turned out to be a sort of pre-campaigning. Guebuza was welcomed at the border of the district by local political and government officers and by crowds of Muidumbeans wanting to see their future president [Fig. 1]. The crowd waited, standing and

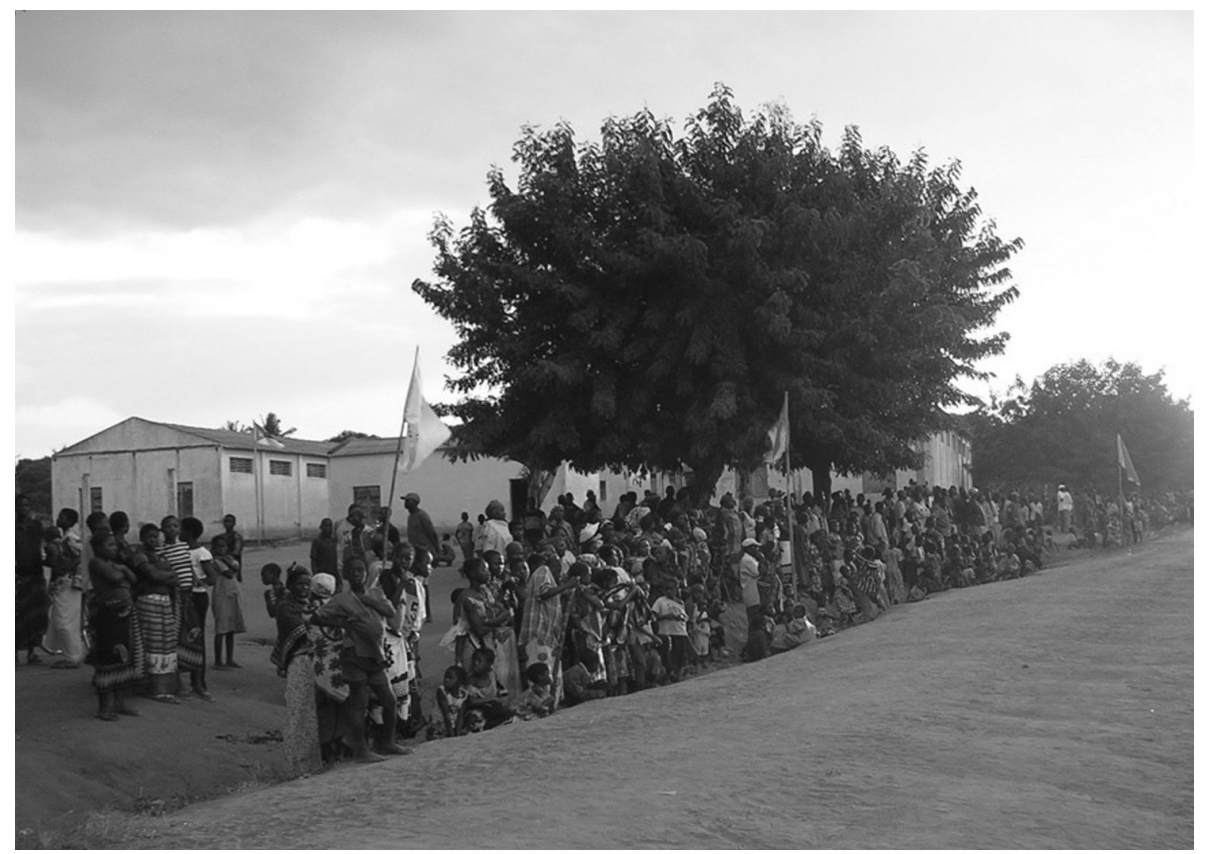

Fig 1. Crowds wait for the passage of Guebuza in the village of Miteda, as the sun begins to set, $11^{\text {th }}$ of August 2004 (Paolo IsraelC)

\footnotetext{
${ }^{8}$ I have not recorded this song, I quote it by heart.
} 
singing, the whole afternoon. Guebuza only showed up at nightfall. Wherever his caravan of cars passed through the villages, headed to the centre of the district, it was greeted by crowds of people, cheering, applauding and chanting the name of the President: "Dabusha! Dabusha!"'.

During the political meeting that followed, the village of Mwambula was overcrowded with people coming from all over the district. Muidumbeans were offered a presentation of Guebuza's curriculum vitae, and of his political programme. Finally, the candidate reunited in a separate place with the local notables to discuss the concrete political problems of the district.

\section{Campaigning for Glory}

Guebuza would not visit the district again during the campaign proper, which started the $17^{\text {th }}$ of October. However, Frelimo's electoral machine was put into motion. A small truck was sent from Pemba, coming from the Provincial Direction of the War Veterans, to transport Frelimo activists. In the district, the distinction between the government and the party is all too thin, and nobody made much fuss about the party using a governmental car. Actually, since the truck was identical to the administrator's, people often could not tell the difference between the two.

The truck visited every single village in the district, carrying along some Frelimo activists, as well as one dance group at a time. It was provided with megaphones, that blasted in the villages of Muidumbe the official tape of Guebuza's campaign, produced in Maputo and sung mostly in Chichangana ${ }^{10}$.

Frelimo's campaign in Muidumbe was devoid of any political content. The meetings in the villages amounted to no more than a detailed explanation of the right place to put a mark on the ballot paper [Fig. 2]. People did not have to be convinced to vote for Frelimo, they had to be instructed to vote properly. Programs and policies were not discussed at all. From a political point of view, the campaign in Muidumbe was actually a pointless exercise. Nobody ever doubted for a moment that Renamo would receive more than a few hundred votes in the whole district. For the dance groups, being involved in the campaign was an important recognition of their affiliation to the party. For villagers, it amounted to a form of identitary celebration.

The real political stake of the elections in the northern part of the province was the city of Mocimboa da Praia, tradionally a Renamo stronghold. In late November, trucks full of dance groups, politicians and electoral materials (t-shirts, bandanas, kangas) left Mueda, Nangade and Muidumbe, headed to Mocimboa, where an enormous meeting was being held. The support of Makonde people was deemed necessary to win the city and to secure victory in the province ${ }^{11}$. The Mocimboa meeting was a demonstration of muscle of the Frelimo's electoral machine.

${ }^{9}$ This is the way that Guebuza's name sounds in Shimakonde.

${ }^{10}$ The title of the tape/CD, produced by FreLimo and interpreted by various artists, was: Armando Emilio Guebuza, A força da Mudança (Maputo, 2004).

${ }^{11}$ The importance of Mocimboa has been dramatically revealed in the riots and confrontations that occurred in this city in 2005. In late November 2005 Pedro Justino Seguro, former 


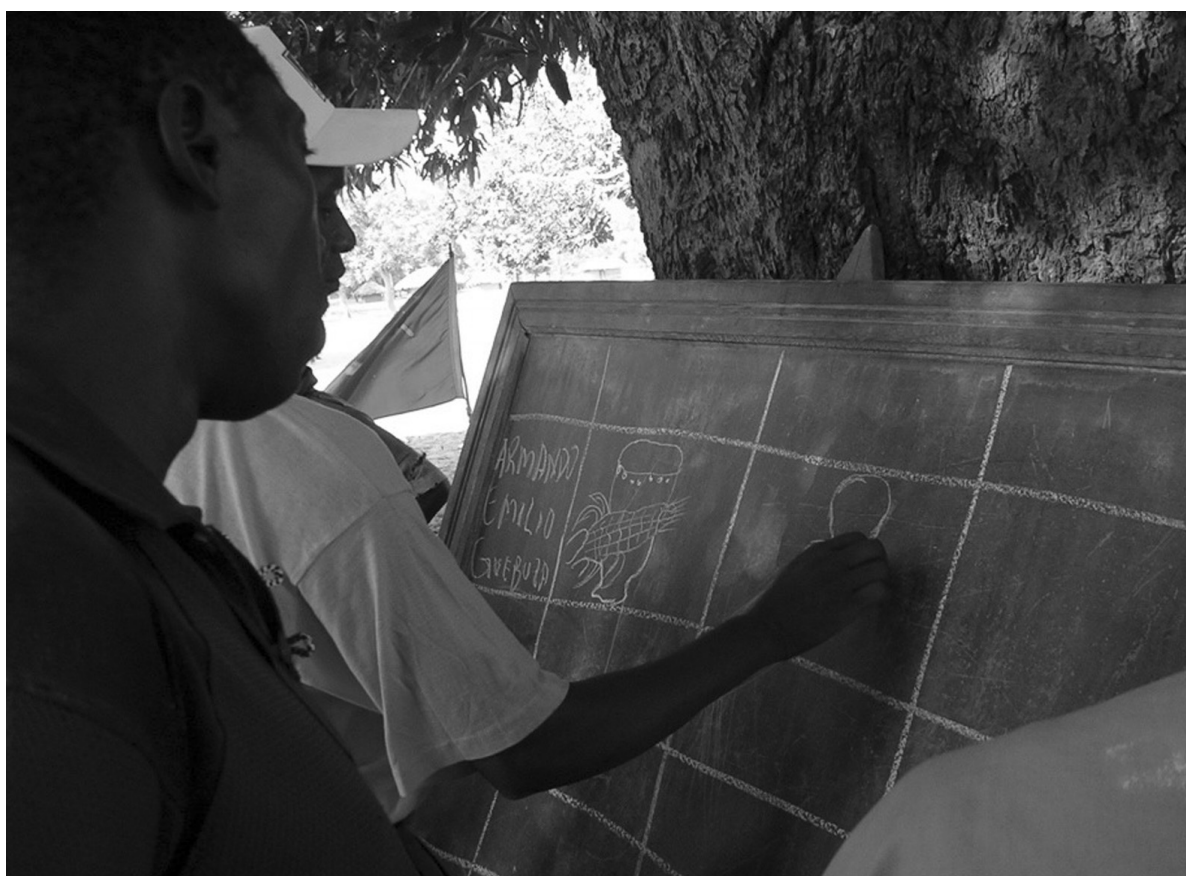

Fig 2. Campaigning in the village of Namande amounts to explaining how to vote, $11^{\text {th }}$ of November 2004 (Sandra Lourenço())

\section{And Renamo?}

Renamo in Muidumbe is almost inexistent.

Muidumbe was the area in the Makonde plateau that was more vulnerable to Renamo warfare during the civil war, because of the proximity with the districts of Macomia and Meluco, inhabited by Makua people. The Makonde people did not support Renamo, except for a few isolated individuals who had suffered violence from Frelimo, directly or indirectly. Towards the end of the war, Renamo militias attacked, plundered and burned villages in the lowlands on the south-eastern slope of the plateau. Those militias were mainly composed of Makua people coming from other districts. As a form of retaliation, Makonde popular militias were sometimes carried around in cars and ordered to kill presumed Renamo supporters in villages faraway from their homes ${ }^{12}$. In 1991 Renamo troops occupied and held the mission of Nangololo in the seat of Muidumbe for a few days.

The majority of the votes for Renamo in Muidumbe come from some three hundred people living in the proximity of Lake Nguri, in the lowlands. Those

administrator of Muidumbe, informed me that the confrontations had led to ethnic tensions between Makonde and Mwani people. Six houses of Renamo followers have been burned in the village of Nshinga in 2005, and Mwani people that used to grow crops in the lowland areas in Muidumbe are not anymore allowed in by Makonde residents.

${ }^{12}$ This piece of information comes from a testimony that for obvious reasons I keep anonymous. 
people are not Makonde, and were displaced in the 1980s in the context of the infamous operação produção. In the plateau, an average of 15 villagers for each village vote for Renamo ${ }^{13}$.

Being labelled as a Renamo supporter in Muidumbe is almost equivalent to social death ${ }^{14}$. The two district representatives for Renamo are systematically harassed and threatened, so they do not tend to publicize their affiliation. They were even reluctant to show up at STAE and at the district level commission for electoral transparency, that were factually led by Frelimo members. Muidumbe, an otherwise obscure district, won a place in the national press because of acts of violence committed against a Renamo representative ${ }^{15}$.

The unbalance in political power, prestige and consensus between Frelimo and Renamo in Muidumbe is overwhelming. There is no surprise that Frelimo won the district with about $90.4 \%$ of the votes, and that Guebuza defeated Dhlakama and the other candidates with $93.2 \%$.

\section{The Intermingling of Ritual and Politics}

In Muidumbe, the end of the year is not only the time of elections and mangoes. It is the time when initiation rites are held. These rituals are among the foremost social institutions of the Makonde people in particular, and of the matrilineal peoples of Central-Northern Mozambique in general $^{16}$. From November to January, boys and girls in their puberty pass through several rituals meant to open the doors to adulthood and eventually marriage. Initiation rituals are the single most powerful, albeit waning, cultural institution in Makonde society, the one that defines belonging, affiliation and completeness of the individual.

For the entire duration of the ceremony, both boys and girls are secluded from the uninitiated and from opposite gender peers and elders. The girls are hidden in the houses, allowed to walk around only wrapped in capulanas (kangas). The boys live in a special hut constructed in the bush around the village (likuta). During this time, and afterwards before they marry, they are given the name of mwali (pl. vali). Boys and girls undergo several rites of passage, often connected to sexual growth, and are disclosed the gendered secrets concerning masquerades and initiation.

${ }^{13}$ Villages vary in size from 500 to 7,000 people. In the field I had the possibility of glimpsing the preliminary data, divided by village, of the elections.

${ }^{14} \mathrm{Mr}$. Shuluma, war veteran and owner of a public service car was suspected of being connected with Renamo just because he participated once in a funeral ceremony in Maputo with the Renamo leader Vicente Ululu. This label stuck on him for years, and people became unwilling to use his car. He had to retire for some time in Maputo until the rumour lost momentum. Shuluma volunteered his car for the general elections of 2004 as a way to definitely remove this stigma.

${ }^{15} \mathrm{He}$ was provoked and insulted by a couple of youngsters in his native village. As he pursued the insulters, other people were setting fire to his house, other again luring him into a trap. He could only save his child that was suffocating from the smoke, and take temporary refuge in Pemba. The district government took no stance to protect him.

${ }^{16}$ On Makonde initiation rituals, see Dias \& Dias 1970. 
After the boys and the girls pass the final rituals of the initiation, they are ready to come back to the village as new persons. This is called "coming out" of the initiation (kujaluka). To symbolize the joy and the importance of this moment, vali are dressed as elegantly as their parents can afford, generously anointed and drenched in overabundant quantities of perfume. Then they are presented to the village in a public ceremony, during which they dance and sing. When they return to their homes, they are reintegrated in society as accomplished women and men.

During the ritual, the mothers and fathers of the young boys and girls must comply with a number of interdictions, concerning food, daily life and sexuality. They wear a special collar that indicates their status as a parent of a mwali. The act of tying this collar is called kwangalela. Kummwangalela is the form that this verb takes when it refers to somebody, and it has the additional meaning of: taking in charge, protecting ${ }^{17}$.

\section{Kummzrangalela Guebuza}

Two weeks before the elections, a group of approximately 30 women in Muidumbe decided to hold a ritual to propitiate the victory of Frelimo's candidate ${ }^{18}$. They pretended that Guebuza was a child going to the bush in order to pass the initiation rites. They performed all the necessary rituals and they laced the collar that symbolised their commitment to the ceremony. By doing so they recognized him as their son and they took upon themselves all the ritual restrictions connected to this act. In shimakonde they expressed it in this way: "tundimmwangalela Guebuza", we took in charge Guebuza.

The women that composed the group were by all standards notable women in the district: war veterans, leaders of the party, leaders of the Mozambican Women Organisation (OMM). The district leader of OMM headed the group, and all the ceremonies were held at her place.

The results of the elections were supposed to be divulgated the $17^{\text {th }}$ of December. However, due to technical problems, the public announcement was only made the $21^{\text {st }}$ of December. All the district was quietly waiting for the final results. The group of women who had joined together to perform the ritual waited for the results near the Frelimo building. As expected as the victory was at this stage of the process, the outburst of joy and exultation was impressive. The women danced, sang and enacted a little theatre representing Guebuza in triumph and Dhlakama crying [Fig 3]. The Party recommended to postpone the partying the day after, so that it could be organized properly.

The women of the OMM group had no physical mwali to present to the village (kujalula). They thought of performing the coming-out ritual either on the district administrator Seguro or the district secretary of Frelimo, Shivavi. Neither of them would have refused to go through the ritual, although as one might understand they were not particularly enthusiastic about it. Word of this reached the women, and this part of the ceremony was skipped.

${ }^{17}$ The added " $\mathrm{m}$ " is the object infix.

${ }^{18}$ West describes the making of Chissano into a umu (clan counsellor, pl. vaumu) during the election of 1994 (West 2005: 259-261). During the campaign day in Mocimboa da Praia, white "ити" bandanas were distributed to all Frelimo supporters (see note 11). 


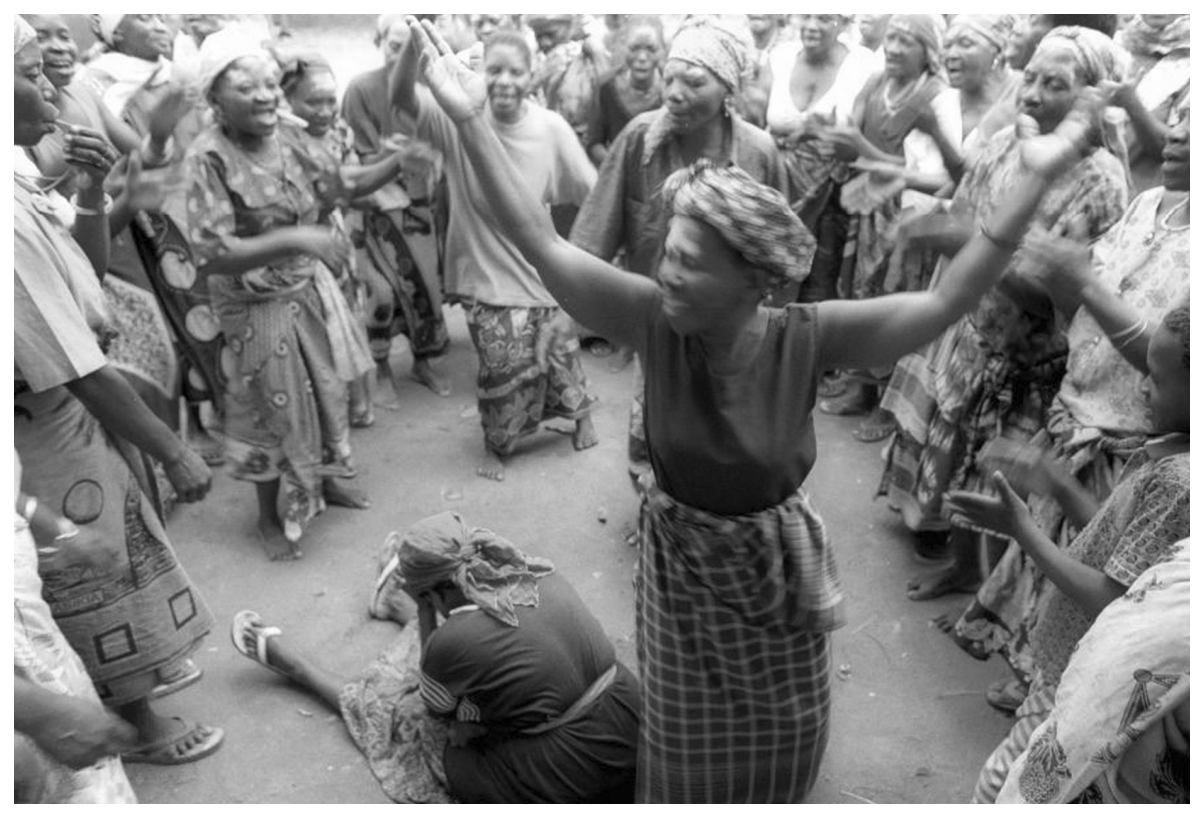

Fig 3. Women of the OMM in Mwambula (Muidumbe) enact the victory: Guebuza sings, Dlhakama sits down and cries, $21^{\text {st }}$ of December 2004 (Sandra LourençoC)

The morning of the day after, the women removed the collars and made them disappear by burying them. They prepared, then, for the final stage of initiation rites: announcing to the neighbours the coming out of their children. The whole group of women dressed in Frelimo flags and Guebuza t-shirts and caps, which were offered by the party, and set out by foot to the nearby village of Mwatide, reputed to be a Renamo stronghold ${ }^{19}$. When arrived in Mwatide, they knocked on the doors of dozens of houses and stores, bringing the good news and asking for food or a small amount of money, that they were unstintingly offered. The spree ended at the house of one of the most venerable war veterans of the district, who had been a member of the first group of soldiers trained in Algeria. The group passed by the house of the deputy representative of Renamo. The house was closed. When the man was spotted, sneaking away, some of the women proposed to follow him and give him a lesson on the spot. Finally, peacefulness prevailed and the man was left alone, as the women set to return to their homes.

Guebuza was not only president of Mozambique. He had been ritually integrated in the social body of Muidumbeans as a Makonde initiate, albeit in absentia.

${ }^{19}$ Which means that Renamo takes there more than a handful of votes. Actually, often a village is singled out as a Renamo stronghold because of petty crime, because people identity all criminal activity with Renamo. 


\section{The Transformation of Initiation Rites}

The political adaptation of likumbi, or in other terms the spelling of politics in a ritual idiom, is not at all foreign to Makonde culture.

After the war of independence, initiation rites underwent a radical transformation. Inspired by a modernist marxixt-leninist ideology, the Party was keen in condemning initiation as well as other traditional practices as obscurantist and antirevolutionary. The Makonde people resisted strenuously against the eradication of initiation rites and gendered secrets ${ }^{20}$. However, they spontaneously adapted the ritual to the post-war setting. The rituals were set in the rainy season to accommodate the school calendar.

Moreover, their content was radically reshaped. During pre-war times the boys practiced Mapiko masquerade and the girls women's dances such as Shinyala. Since the end of the war and up to now, the main cultural specific content of the training imparted during the rituals has been the learning of the makwaela dance. This dance originated among migrant workers from Southern Mozambique in the South African mines, some 2,500 km. away from Muidumbe. It consists in harmonized choral singing and foot-stamping. Because of its socially progressive nature and of its simplicity, it was chosen already during the war as the favourite cultural activity in the new Frelimo schools and training centres. After the war, it became a sort of new national icon, the revolutionary dance par excellence.

Initiation rituals are about instilling into boys and girls the qualities, attitudes and competences that make of them full-grown members of the society. The inclusion of makwaela dance and revolutionary songs into initiation rituals responded to a change of perception of what adulthood was about in rural Makonde post-war society.

The transformation of the ritual suggests a radical change in the shared definition of what being a full-grown Makonde woman or man is about. After the war of liberation, this came to include: a bodily experience of the construction of the nation through dance; the absorption of the mythology of the war of liberation through the learning of songs about its heroes, dates and events; the interiorization of its symbology through the use of flags and tissues.

\section{The Ritualization of Politics}

Initiation rites were not the only traditional item that had been given new political meaning. Makonde masquerades, Mapiko, incorporated the symbology of the Party in their masks and in the paraphernalia (arms, flags, etc.) used by the dancers. Moreover, new revolutionary songs replaced the old colonial time songs based on provocation and local lore.

At the same time, when ritual was politicized, the political life of the nation was increasingly being ritualized. This happened mostly on account of the Leninistinspired policies of communication and mass organisation adopted by Frelimo.

\footnotetext{
${ }^{20}$ Josina Machel was particularly keen in promoting gender awareness in the guerrillas. However, oral testimony indicates that the people were not open to allow the party to intrude in these questions during the war.
} 
Mapiko masks and dance groups started to participate in meetings and political events well before independence. The intermingling of politics, popular culture and ritual was experimented early in the revolutionary process, in the camps and bases of Frelimo in northern Mozambique and Tanzania (Siliya 1996).

The ritual being politicized and politics ritualized, the distinction between the two spheres became all too blurred. This explains the formal aspect of the propitiatory likumbi organized for Guebuza. It does not, however, pose the ultimate question. Why in the first place did the Makonde people allow Frelimo symbols, myths and ideology to be a defining factor of adulthood in their initiation rites and an identitary milestone at large?

\section{Makonde and Frelimo: Social Palingenesis}

Ethnicities (particularly in Africa) are not timeless and static, but very often are the product of recent socio-political events, sometimes a reflection of the external gaze, whether of neighbours, of the colonial agents or of the brokers that cooperated with them ${ }^{21}$. However, ethnicities often reflect real social, cultural and linguistic differences, that should not be underestimated in an all-constructivist approach. Ethnogenesis and ethnic identity are not local phenomena, and ethnicities should be apprehended in the widest context of the chain of societies that they are embedded in (Amselle 1990).

I assume that ethnic identity is structured around the reciprocal interaction of two components: "cultural identity", which is ideology-driven and constructed, influenced by representations of the self and the society (both internal and external), and by the position of the society within a local and global system (Friedman 1994) ${ }^{22}$; and "hard" traits of the society, which include language in the first place, and then material culture, mode of production, and social organization (kin, etc.). Cultural identity can select and reorganize these hard traits to make them express different configurations of inclusion, exclusion and self-representation ${ }^{23}$.

For instance, clusters of languages can be analysed more or less objectively through lexicology and grammar. However, local linguistic taxonomies do not necessarily correspond to objective differences between languages, but are determined by linguistic ideology. Each single variant in a continuum can be classified differently as a "dialect" or a wholly different language to defend dynamics of inclusion, exclusion or differentiation that are driven by linguistic ideology. The same might

${ }^{21}$ It is out of the scopes of this paper to give a bibliography on ethnicity. For a general compendium, see Poutignat \& Streiff-Fenart 1999. For constructivism, see Amselle \& MBokolo 1985, VAIL 1989. For a very even-handed approach to the question of ethnicity, see Lentz \& Nugent 2000.

${ }^{22}$ Following Friedman, I argue that definition of cultural identity must take into account the position of the society in the world-system in which it is embedded, and the civilization cycle of the same global system.

23 "Ce qui relève du domaine de l'ethnicité, ce ne sont pas les différences culturelles empiriquement observables, mais les conditions dans lesquelles certaines différences culturelles sont utilisées comme des symboles de la différenciation entre in-group et out-group" (Poutignat \& StreiffFENART 1999: 141). 
apply to other important cultural institutions, that might or might not be assumed as cornerstones in the definition of a particular identity.

This implies that not all identities have the same "thickness". Some ethnic identities shape the hard traits that make their social institutions into more inclusive or cohesive ensembles ${ }^{24}$. Some ethnicities have a longer history, some are structured around more distinctive hard traits that make them more cohesive, some are fragile and tending to desegregation. The world is nothing similar to a puzzle of identities with the same status and depth of embedment. On the contrary, ethno-scapes are about different levels of relief, profile and thickness of identitary affiliation.

\section{Makonde Ethnogenesis}

The precolonial history of Northern Mozambique suggests that the Makonde people were splinters of the Maravi people, who were organised in an empire that extended its influence from the south of Lake Malawi to the region of Kilwa (Dias 1964, Kingdon 2002, West 2005). Together with Yao people and the people of the Rovuma river they share important linguistic and cultural similarities with the Chewa ethnicities of Malawi. It might be guessed that some of the people of northern Mozambique and Tanzania, whose languages bear resemblance with Maravi languages like Chichewa, are the descendants of groups of Maravi people that settled over the course of time around a commercial route linking Tete to Kilwa (Hamilton 1954, Rangeley 1954, Newitt 1982²5. Those people's languages (Shimakonde, Chiyao, Kindonde, Shimatambwe), on the contrary, have no close links with the Emakhuwa linguistic group that spreads from the Zambezi to the Rovuma river.

Makonde ethnic identity emerged as a response to the slave trade somewhere in the first half of the $19^{\text {th }}$ century $^{26}$ (West 1997; 2004). The Yao people had reorganised as a semi-patrilineal, Islamic society, taking the lead of the slave caravans in the regions ${ }^{27}$. People living around the Rovuma river started to retire on the high plateaux to flee the slave raids. Eventually, those refugees came to call themselves Makonde, which is a geographical name linked to those plateaux ${ }^{28}$.

In the late $19^{\text {th }}$ century, the Makonde people were refugees living on the brink of destruction, partly engaging in and mostly defending themselves from the slave trade $^{29}$. They lived in independent fortified villages, occasionally trading with the

24 “[...] l'ethnicité ne se définit pas comme une qualité ou une propriété attachée de façon inhérente à un certain type d'individus ou de groupes, mais comme une forme d'organisation ou un principe de division du monde social dont l'importance peut varier selon les époques et les situations" (Poutignat \& Streiff-Fenart 1999: 136).

${ }^{25}$ I am indebted to Malyn Newitt for this observation (personal communication).

${ }^{26}$ E. Alpers pointed out the existence of early reference to the name "Makonde" in the historical records, that might suggest that a core of people living in the plateau existed before the $19^{\text {th }}$ century and called themselves "Makonde" (personal communication).

${ }^{27}$ On Yao shift from a pure matrilineal system to a mixed one, see Verdon 1995. On the role of the Yao in the slave trade, see the classic Alpers 1975.

${ }^{28}$ Yao too is a geographical name.

${ }^{29}$ See WEST 2004 for the way that Makonde were cast in the roles of victims of the slave trade by the British consul E. O’Neill. 
coast and neighbouring people (O’Neill 1885; West 2004). Eventually, they came to be feared in the region because of their aggressiveness and savagery, which was probably also an form of defence against the trade. That renown earned them the depreciative name of Mavia ("the nervous").

I argue that this shared historical experience of resistance to slave trade forged a collective consciousness of insoumission (un-submission), craving for freedom and independence that the Makonde people took with them once they were pacified by the Portuguese in 1917. As the slave trade was put to an end, the Makonde people started to expand again in the lowlands around the plateau and to travel in neighbouring Tanzania in search of work $^{30}$.

\section{Luta Armada}

Frelimo was founded in 1962 by a group of people coming from three pre-existing political organisations ${ }^{31}$. One of them was the Makonde African National Union, organised by Makonde emigrates in Dar-Es-Salaam. Makonde people had emigrated massively to Tanzania, where they had come to know the benefits of freedom and independence. When the option of armed insurrection was chosen, it seemed natural to chose the plateau of Mueda as one of the centres of military operations, because of the support that Makonde guerrillas could have enjoyed, because of its proximity to the Tanzanian border, and because of its thick bush that would have helped the guerrillas to hide.

These reasons do not account for the massive participation of Makonde people in the war of independence. Whole villages were abandoned, as people left to live in the bush to support the war with their work. In spite of the political violence that marked the first years of the formation of Frelimo, the bulk of the Makonde people stayed faithful to its leaders through thick and thin. People endured hard life, military discipline, war with the Portuguese, the risk of being caught by Pide (Policia Internacional e de Defesa do Estado) or either to be sent to one of the infamous Frelimo re-education camps ${ }^{32}$. I cannot but see a connection between this extraordinary collective enterprise and a long tradition of resistance that had been built up during the slave trade. Colonialism simply could not be endured, and Frelimo was ostensibly the only way to fight it.

The dramatic, collective experience of the war and its aftermath left a deep mark on a whole generation and had the result of transforming wholly and rad-

${ }^{30}$ I do not deal here with the period of "consolidation" of Makonde ethnic identity during the colonial time. I will treat this theme, through the analysis of Mapiko masquerades, in two chapters of my doctoral dissertation in progress. About the migration of Makonde people, see Kingdon 2002, Alpers 1984.

31 Bibliography on Frelimo and the Luta Armada is vast. For references, see NewITT 1995, Henriksen 1983, Isaacman \& Isaacman 1983. For Makonde participation, see Adam 1993 and Gahen 1999.

${ }^{32}$ In constructing, as I try to, a genealogy of the fidelity of Makonde people to Frelimo, one should not underestimate the importance of political violence exerted by Frelimo since the times of war and well after. Gathering evidence of this violence is not easy. It often comes in the form of half-muttered anecdotes referring to someone else, when it comes at all. In most of the cases, "bad guys" in the Party are stigmatized for the violence, and not the Party itself. 
ically the Makonde society. If there is any place in Mozambique where Frelimo engendered a real revolution, this is the Makonde plateau. In order to give a general idea of the scope of these radical and enduring transformations, I have tried to summarize them under the most important headings. Each single item in the list that follows could be (and in some cases has been) the object of an indepth study.

Change of the residential patterns. The Makonde people lived in kin-based matrilineal small settlements, with population ranging from a few nuclear families to some hundred people. During the war, they lived in conglomerates of small huts hidden under the trees of the bush, mainly in the lowlands. At the end of the war, they embraced the project of collective villages promoted by Frelimo, building hundreds of organised villages that gathered people from different settlements and clans (West 1998).

Unification. Until 1964, Makonde society was acephalous, segmentary and subject to inter-clan warfare. The war effort led to the unification under Frelimo, not without problems in the very first phase. Ever after, Makonde guerrillas stayed loyal to the Frelimo leadership throughout the war, in spite of massive internal strife in its leadership in 1967-68 and widespread political violence in the military bases in Cabo Delgado.

Education and nationalization. During the first years of war the Makonde people were exposed to the education system put in place by Frelimo in its liberated zones, which was based on the idea of the construction of a Mozambican nation and the merging of Mozambican ethnicity in a new social body (Alpers 1983, Siliya 1996).

Militarization. Makonde people were widely trained in the use of weapons and modern war techniques.

Regional prestige. During pre-colonial times, the Makonde people had mostly played the part of the losers and refugees in the regional networks of slave-trading $^{33}$ (West 2004). At the end of the war of independence, they were re-cast in a dominant role in the regional equilibrium of power between different ethnicities.

Collectivisation. After independence, the Makonde people experienced the ideology and the implementation of projects of collectivization promoted by Frelimo: cooperatives of production, collective farming, etc.

Waning of traditional power. The new structures of power of the Party tended to replace authority based on kinship in the communal villages. Kin-based leaders still play a role in the resolution of familiar disputes and in the managing of questions linked to the "invisible realm" (West 1998, 2005).

Empowering of a new generation. The war empowered a generation of young people that took arms sometimes in opposition to their elders. Young people were authorised to threaten and even kill their elders if they refused to ally with Frelimo, which was unthinkable in previous times ${ }^{34}$.

${ }^{33}$ The retreat to the plateau was actually a successful strategy against slave trade.

34 The demise of the elder Lazaro Nkavandame was made possible by a strategic alliance between the group of southerners that was at the head of Frelimo and young Makonde leaders, such as Chipande, Pachinuapa and Lagos Lidimu (for Nkavandame, see Gentili 1991). 
Transformation of gender relationships. Women participated in the luta armada as soldiers and as commoners. The ideology of Frelimo defended gender equality, opening stunningly new opportunities to girls, who were widely empowered in the process (Isaacman \& Isaacman 1984; West 2000). In the communal villages, the male-centred structure of the pre-independence settlements disappeared.

Internationalization. Makonde people travelled far abroad to be trained militarily: Israel, Algeria, URSS, China. Those experiences broadened the horizons of many people who later returned to live in their rural villages.

Scattering. At the end of the war, Makonde war veterans were scattered in the main cities of Mozambique, to promote Frelimo policies with people who had not been exposed to them, and also to prevent the concentration of militarily trained people in a single area of the country. Today, Makonde people own and often distribute land in zones far-away from the Makonde plateau.

Devalorisation of tradition. Following the anti-traditional, modernist policies of Frelimo, "traditional" practices and rituals were de-valorised as superstition or obscurantism (West 2005).

Valorisation of culture as national heritage. Some items of Makonde culture, in particular blackwood sculpture and masquerades, were valorised in the country as part of an inalienable national heritage (Alpers 1989; Mkaima 1997).

National prestige. At the end of the war, the Makonde people came to be known in the whole country as fierce warriors and fine artists, broadcasting a renown that did not go far around their area of settlement before of the war.

Common epos ${ }^{35}$. The war of independence was a sort of epic tale for a whole generation. A number of individuals constructed their personal identity during those dramatic years, transmitting historical knowledge to the new generation in the form of art, songs, stories and masquerades [Fig. 4].

The war and the post-war revolution did transform Makonde ethnic identity from the point of view of social organisation, ideology and identity. Frelimo was at the heart of all these transformations: the social changes, the nationalist and revolutionary ideology and the new epos of liberation were all novelties brought by the war and by the reorganisation propelled by Frelimo.

A commonplace saying in Shimakonde goes: "Frelimo ni shinu shetu wetu" (Frelimo's our own thing). This implies not only an affirmation of the purest pedigree in the genealogy of the nation, based on historical deeds ${ }^{36}$. It conveys also the reverse idea: the interiorization of Frelimo as a fundamental component of what makes "our own thing". If factually Frelimo isn't Makonde's “own thing”, it contributes heavily to shape what is Makonde's "own thing", what Makondeness is about. In other words, the saying suggests that Frelimo is at the heart of the definition of Makonde ethnic identity.

\footnotetext{
${ }^{35}$ I use this term in the sense of given by the Wordnet dictionary of the Princeton University: "A body of poetry that conveys the traditions of a society by treating some epic theme". In this context, "poetry" must be intended as including different genres of creativity: masquerade, popular song, dancing.

${ }^{36}$ Often the saying is used to underscore the imbalance between the role that Makonde people played in the war and their actual state of political forsakenness. One could say Frelimo shinu shetu, when faced to the abuse of an official from Pemba, for instance, as a way to intimidate him.
} 


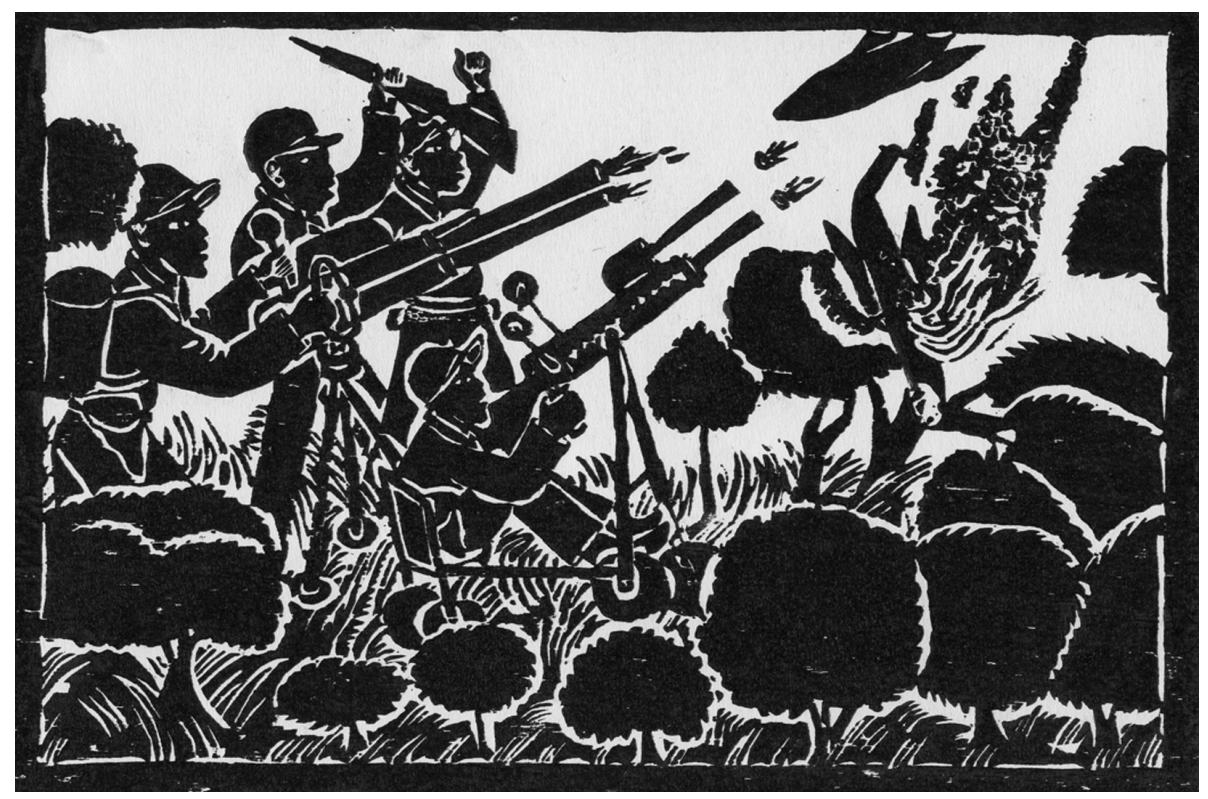

Fig 4. Anti-aerial combat during the Luta Armada (Matias Ntundu(C, xilogravure)

The Frelimo which is Makonde "own thing" is not the real political party as a historical entity. It is a construct of the imaginary - built upon factual and dramatic socio-political changes; on an ideology of modernism, universalism, socialism and well-being spelled in vernacular idioms; and on a identitary epos conjugated in an amazing spectrum of popular expression.

\section{Renamo: the Enemy Within}

Frelimo in Muidumbe is not only a political party. It is a figure of the imaginary embedded into the very foundations of society. Under such conditions, to criticize it amounts to a painful distancing from the myths that Makonde society is founded on.

Looking on the other side, what does Renamo represent at large in Muidumbe? Why does it appear heinous to Muidumbeans to such an extent that every public representation of sympathy for this political party is considered as an act of subversion and wickedness, eventually leading to social exclusion or physical threat? Could this be attributed only to the memories of the times of war? Why then should resentment linger on in the Makonde plateau, whereas in other parts of the country where the damage caused by the civil war was much more severe, people are more willing to forget and forgive?

\section{Songs of Provocation}

Popular songs are an excellent entry point to analyse collective political representations, because of the peculiarity of their creative processes. Popular songs are 
often the creation of a single individual, who either rearranges pre-existing materials or creates wholly new idioms. However, the spread of the song is due to the capacity that it has to channel collective feelings and representations into a single idiom $^{37}$.

Starting from the 60s, Shimakonde popular singing turned political in content and form. Shimakonde popular songs constitute a precious political commentary of the socialist project in Mozambique.

Many of these widespread political songs refer to Renamo.

In songs, as well as in common language, Renamo is never referred to directly. A number of euphemisms are used to identify its followers: mashanga (from the name of Renamo's leader, André Matsangaissa); nanamu (which is the name of a stinking worm); lyakogwe (another kind of worm); vanambili (the animal which is the symbol or Renamo). The most widespread of all nicknames is matunu (sing. litunu), which refers to the ugliest of the African animals: the nocturnal, treacherous, scavenging hyena.

We can divide the songs that refer to Renamo in three main categories: songs of remembrance; songs that intend to raise political consciousness; electoral songs.

Songs of the first category refer to the hideous acts committed by Renamo during the civil war. Sometimes they refer to precise events (a song has been composed on the invasion of the plateau); sometimes they paint a general portrait, like this one:
Ndikwamba wako Dhlakama
Ikadi yako akata nyani?
Mulo' vitendo vyamushitenda mudialudeya
Kunkodya munu washitumbu
Kutwa' shipula kumbavola
Kummumya mwana ndikidiki
Kunjanikila

I am referring to you, Dhlakama

Who is going to tear apart your card?

Look at all the things that you did in the villages

Find a pregnant woman

Take a knife, desembowel her

Take out a little child

Roast him on a broach

The second category of songs aim to prevent the infiltration of Renamo in social and political life. Renamo members are depicted as treacherous, sneaking and dangerous people, wolves in sheep's clothing. The one that is the heading of this paper fits into this category, as well as the following:

Pamwidumbi tulilaledye matunu

Digabinete vandibabola pa Mwatide

Vandyuka naikala pa Myangalewa

$\mathrm{Pa}$ Lutete mulilaledye

Matunu andyumbalanga apa
We have to be careful in Muidumbe with hyenas

They have shut down their office in Mwatide

And went to stay in Myangalewa

In Lutete we have to pay attention

It is full of hyenas

37 For instance, see Joan Baez's commentaries on the capacity that Bob Dylan had to channel the spirit of the civil rights movement of the $60 \mathrm{~s}$, in spite of his apolitical personal stance (in Scorsese, No Direction Home, film documentary, 2005). 
Songs referring to elections are in a wholly different style: playful, brave and provocative. Sung before and after the elections, they defy Renamo to win the election and mock it when it loses them. They ofter personify Renamo in its leader, depicting him in the most embarrassing and ridicolous situations.

\author{
Jakama ajó \\ Jakama nelo \\ Jakama alya uwangu kumaundu-ko \\ Tundimmwima wetu dikula dyetu \\ Tundimmwima aikele \\ Jakama kulila: paushagushi \\ mungutandole \\ Aí! Wetu atutamwa \\ Aíi! Wetu atutamwa tundintandola \\ baba Guebuza \\ Jakama nnambele jó \\ Mpaka mukankodye palila po
}
Dhlakama, this one
Dhlakama, today
Dhlakama eats cowhage ${ }^{38}$ in an abandoned field
We refused to give him our votes
We refused so he sat down
Dlhamaka is crying: vote me at the elections!
No! We don't want to
No! We refuse! We have voted papa Guebuza
Dhlakama, go and search for him
Until you find him where he's crying

\section{The Cultural Roots of Competition}

In pre-1964 Makonde society, acts of provocation were seen as a test of courage for a young man willing to show his bravery in the face of his own kin. Provocation (ushaka) could amount to kidnapping women of a different clan, taking hold of goods, or even provoking inter-clan warfare.

Mapiko masquerades were also a ground for provocation and taunting. Pre1964 popular songs connected to Mapiko masquerade and other dances were either related to the lore of elderly people, or to the taunting of adversaries and people from the neighbouring settlements. All too often this taunting was quite successful, and Mapiko competitions ended up in bloodshed. Traditional taunting songs could be extremely provocative, often referring to the moral and physical qualities of the women of the nearest village, to the lack of bravery of their men, or to their artistic inconsistence. Winning or losing a Mapiko competition was a way to assert the superiority of one's likola (clan) against another.

The war and independence brought a new spirit of solidarity and unity (upamo). This applied also to dancing, where taunting songs were banned more often than criticized. Taunting was not anymore considered an act of bravery and provocation (ushaka) but an anti-social habit of language (iyanje, that could be translated as "idiom of envy"). Taunting is still moderately allowed in two forms: asserting one's artistic mastery (ulanda) and imputing to other people bad speech habits (iyanje).

Competition between dance groups was slowly brought into a less violent context. Soon after independence, Frelimo started to organise dance festivals (mashindano), in which groups could confront each other on the grounds of artistic mastery,

\footnotetext{
${ }^{38}$ Mucunia pruriens, an urticating inedible species of bean. In Portuguese: Feijão-macaco (Feijão maluco).
} 
being judged by a competent jury. Although losers never accept publicly the results (somebody has always been robbed) they conform themselves to them. Spontaneous competition between dance groups is based on the cheering of the crowds, and rarely ends up in violent confrontations.

Starting in 1994, elections became a politically acceptable ground in which taunting practices could be resurged. The ideology of national unity prevented the Makonde from despising and criticising other people because of their ethnicity or their kinship. However, despising and having fun at the expense of Renamo was not only accepted, but also encouraged by local authorities ${ }^{39}$. Taunting songs were revived, refined and reinvented to suit the new enemy - Renamo. The electoral competition (ushagushi, shitandola) turned into a gigantic competition (mashindano) in which the identity of the Makonde people as a whole is at stake. There is no wonder that dance groups participate spontaneously and enthusiastically in such an event.

\section{Relatives, Villagers and Wicked People}

During colonial times, competition between Mapiko groups was a way to assert one's likola superiority over someone other's. People lived in settlements that were affiliated by ties of kinship, but often competing for land and riches.

The war and the nationalist ideology of Frelimo brought to an end intra-kin rivalries. In Shimakonde, a new word was forged to describe citizenship: venentete. Mitete (sing. ntete) was a term used to describe a foreign settlement, as opposed to likaja, one's own settlement. Venentete indicated then the people living in foreign settlements. After independence, all people turned into venentete ("the people", in a Marxixt-Leninist idiom), participating in an abstract national community. In Shimakonde, that suggests that nobody had a home any longer - everybody turned into "people of foreign villages".

The palingenesis of Makonde society was not without deep trauma and violence. Even though the process of villagisation was on the whole well received in Makonde plateau, it did lead to confrontation and strife (Oficina de História 1986). The blame of it all this was cast, following Frelimo's rhetoric, upon counterrevolutionaries and "enemies of the people", symbolised by the popular character of xiconhoca, the lazy traitor of the revolution. Traitors of the party were branded in this category. The experience of summary executions during the war was not easily digested, and counterrevolutionaries were seen as deserving death. A bunch of people were subsumed in the local category of malambi (scoundrels): the early traitors of Frelimo such as Nkavandame and Simango, petty thieves and criminals, and, as one might expect it, Renamo followers.

With democracy, this kind of ideology disappeared at national level. In the Makonde plateau, it is lingering on. However, xiconhocas and counterrevolutionaries are but ghosts of the past that one can evoke with a nostalgic smile. The accusation of being uncivilised was transferred solely and entirely to Renamo. In popular songs, Renamo followers are not represented as people, but as animals

${ }^{39}$ Local radios, however, are forbidden to record and broadcast this kind of song. 
of the worst type (hyenas, worms) that scavenge, sneak, crawl, destroy for the sake of evil. They are enemies of society, and as such should not be allowed to participate in the political life ${ }^{40}$.

Probably a society that was deprived of all kinds of social antagonism in the name of a project of construction of a socialist nation, still needs a imaginary enemy embodying all the fears and negative feelings connected to otherness.

\section{New Generations}

The experience of the Luta Armada has reshaped the whole Makonde society, embedding Frelimo in its very social and ideological foundations. At the same time, it has concretely empowered a single generation of then young men who are now in their $50 \mathrm{~s}$ and $60 \mathrm{~s}^{41}$.

This experience has not been shared by the new generations. During the last visit of Chissano to Mueda that I described earlier, a young student loudly voiced his discontent for the lack of opportunities of employment; the deficiencies of the hospital in Mueda ("we get cloroquine for everything") and for a school system where "only the sons of the ministers go to College". The boy was at once reprimanded and reassured by the president.

The new generations seem not to discard the symbolic place that Frelimo had in their father's achievement of freedom from oppression, and social revolution. They are often able to identify and point out discrepancies between the promises and the facts, the "imaginary Frelimo" and the real one, but they are still able to connect to the ideals that Frelimo represented for their fathers. Will this endure the test of time?

Youths have no spaces in which to express and channel their political disarray, and they do it often in popular culture, be it singing or masquerading. Naupanga is a new youth Mapiko masquerade that has been raging in Makonde villages since 2001, and has asserted itself as the most successful new masquerade ever in the plateau (Israel 2005).

Naupanga commented on Guebuza's rising to power with these enigmatic and ironic verses:

${ }^{40}$ In 2003, I travelled to Pemba with my field assistant Mali Ya Mungu, a 36-year old man, son of an important Frelimo leader, and of a woman guerrilla fighter (DF). Mali Ya Mungu had travelled a lot with his father until he died, in the 80s. He had not been to Pemba since 1989. When we passed near the Renamo seat in the city, he startled: "There is no law nowadays. How it is they allow bandits to have offices in the city?" He insisted that we pass on the other side of the road. He was even more disappointed when he visited his mother in a village near Pemba, after 13 years, and found out that she had turned to Renamo because she was not receiving a pension as a war veteran! He made her remove all symbols and pictures of Dhlakama on the wall before accepting to sleep at her place.

${ }^{41}$ Curiously enough, it is the same generation that empowered itself in Europe with the May 1968 revolutionary movement. Those same people still hold pre-eminent positions of power in the European governments and intellectual establishment. 
Guebuza tundinkodya

Aikele mulukoma

Wetu tunditwala

Alangalele Moshambiki

Kwalala kwalala

Kulamulila Naupanga

Kwalala kwalala
Guebuza, we found him

Sitting in a porch ${ }^{42}$

We took him

And put him to lead Mozambique

It's beautiful

Naupanga rules

It's beautiful
November, 2005

Paolo ISRAEL

École des hautes études en sciences sociales Centre d'études africaines (Paris)

\section{Bibliography}

Adam, Y. 1993, "Mueda, 1917: resistência, colonialismo, libertação e desenvolvimento", Arquivo, Boletion do Arquivo Histórico de Moģambique, 14: 4-102.

AlPers, E.A., 1975, Ivory \& Slaves in East Central Africa. Changing Patterns of International Trade to the Later Nineteenth Century, London, Heinemann.

1983, "The Role of Culture in the Liberation of Mozambique", Ufahamu, XXII (3): 143189.

1984, "To Seek a Better Life; Implications of Migration from Mozambique to Tanganyika for Class Formation and Political Behaviour", Canadian Fournal of African Studies, XVIII (2): 367388.

- 1989, "Representation and Historical Consciousness in the Art of Modern Mozambique" in B. Jewsiewicki, ed., Arts et politiques en Afrique Noire / Art and Politics in Black Africa, Ottawa, Association canadienne des études africaines: 73-94.

Amselle J.-L. 1990, Logiques métisses. Anthropologie de l'identité en Afrique et ailleurs, Paris, Payot.

Amselle, J.-L. \& M'Bокоlo, E., eds 1985, Au cœur de l'ethnie. Ethnie, tribalisme et État en Afrique, Paris, La Découverte.

CAhen, M., ed. 2000, Pays lusophones d'Afrique. Sources d'information pour le développement, Paris-Ibiscus / Pessac-Cean.

Cahen, M. 1999, "The Mueda Case and Maconde Political Ethnicity. Some notes on a work in progress", Africana Studia, 2: 29-46.

2002, Les Bandits. Un historien au Mozambique 1994, Paris, Fundação Gulbenkian.

Dias, A.J. 1964, Os Macondes de Moçambique. Vol. I: Aspectos Históricos e Económicos, Lisbon, Junta de Investigações do Ultramar.

Dias, A.J. \& Dias, M. 1970, Os Macondes de Moçambique. Vol. III: Vita social e ritual, Lisboa, Junta de Investigações do Ultramar.

Friedman, J. 1994, Cultural Identity and Global Process, London, Sage ("Theory Culture and Society Series").

Gentili, A.M. 1991, "Les origines rurales du nationalisme mozambicain. Les coopératives Liguilanilu du Plateau Mueda 1957-1963", Histoire sociale de l'Afrique de l'Est (XIX-XXX siècle), Actes du Colloque de Bujumbura (17-24 octobre 1989), Paris, Karthala: 159-166.

Hamilton, R.A. 1954, "The Route of Gaspar Bocarro from Tete to Kilwa in 1616", Nyasaland Journal, VII (2): 7-14.

${ }^{42}$ To sit in the porch is the epitome of idleness and the lack of any purpose. 
Henriksen, T., 1983, Revolution and Counter-Revolution: Mozambique's War of Independence, Westport, Greenwood Press.

Isaacman, A. \& Isaagman, B. 1983, Mozambique From Colonialism to Revolution, London, Boulder, Westview.

— 1984, "The Role of Women in the Liberation of Mozambique", Ufahamu, XIII (2-3): 128185.

Israel, P. 2005, "Mapiko masquerades of the Makonde: Performance and Historicity", in H. Arero \& Z. Kingdon, eds, Eastern African Contours: Reviewing Creativity and Visual Culture, London, Horniman Museum ("Contributions in Critical Museology and Material Culture Series").

Kingdon, Z. 2002, A Host of Devils. The history and context of the making of Makonde spirit sculpture, London-New York, Routledge.

Lentz, C. \& Nugent, P., eds 2000, Ethnicity in Ghana: the limits of invention, Basingstoke, Palgrave.

Mkaima, M. Costa 1997, "Mapiko Masks, yesterday and today", in K. Fenzel, ed., Makonde: "Mapiko", Lienz, Neue Galerie der Stadt, 163-165.

Newitt, M. 1982, "The Early History of the Maravi", Journal of African History, 23: 145-162. 1995, A History of Mozambique, London, Hurst \& Company.

Oficina de História 1986, Poder popular e desagregação nas aldeias comunais do planalto de Mueda, working document, Universidade Eduardo Mondlane, Centro de Estudos Africanos.

O’Neill, H.E. 1885, "Journey in the District West of Cape Delgado Bay", Proceedings of the Royal Geographical Society, 5: 393-404.

Poutignat, P. \& Streiff-Fenart, J. 1999, Théories de l'ethnicité, Paris, PUF.

Rangeley, W.H. 1954, "Bocarro's Journey. Comments", Nyasaland Fournal, VII (2): 15-23.

Siliya, C. 1996, Ensaio sobre a cultura em Moçambique, Maputo, CEGRAF.

VAIL, L. 1989, The Creation of Tribalism in Southern Africa, London, James Currey/Berkeley, University of California Press.

Verdon, M., 1995, "Les Yao du Malawi : une chefferie matrilinéaire?”, Cahiers d'études africaines (Paris, EHESS), XXXV (138-139): 477-511.

West, H.G. 1997, "Mozambique: Peoples and Cultures", Encyclopedia of Africa South of The Sahara, Middleton, John/New York, Macmillian: 198-202.

— 1998, "This Neighbour is Not My Uncle': Changing Relations of Power and Authority on the Mueda Plateau", Journal of Southern African Studies, XXIV (1): 141-160.

2000, "Girls with guns: Narrating the Experience of War of Frelimo's 'Female Detachment'”, Anthropological Quarterly, LXXIII (4): 180-194.

2004, "Villains, Victims, or Makonde in the Making? Reading the Explorer Henry O’Neill and Listening to the Headman Lishehe", Ethnohistory, LI (1): 1-43.

2005, Kupikilula, Governance and the Invisible Realm in Mozambique, London-Chicago: Chicago University Press. 